\title{
Patelloplasty in total knee arthroplasty with circumpatellar denervation versus without denervation - a randomized prospective study
}

S. R. K. Deekshith *D, K. J. Reddy and R. Raviteja

\section{Abstract}

Introduction: Anterior knee pain is one of the major problems in total knee an (TKA) and is often etiologically associated with a patellofemoral parts etiology. There is no cons cys as to etiology or treatment. Denervation of the patella by electrocautery and patelloplasty with removal of osteophytes have been used for treatment of anterior knee pain in TKA. The purpose of our trady was to compare, in terms of the anterior knee pain and clinical outcomes of patelloplasty in total knee arthrclasty (TKA), patellar denervation by electrocautery and non-patellar-denervation treatment in a 2 ear

Materials and methods: This study was conducted in a total 108 patients, who underwent TKA at our institution between June 2015 and December 2016. Pzrepts age to 80 years, who are suffering from osteoarthritis, rheumatoid arthritis of knee were inclua this study. Patients were randomly allocated into patelloplasty with denervation group and non-d nervatio robup. The denervation of the patella was done in electrocautery group using a monopolar coag ala. diathermy set to 50 W. (Valleylab Inc., Boulder, CO).

Postoperatively, patients were assessed at refular in als of 3, 6, 9, 12, 24 months. To assess patient outcomes, we used questionnaires to determine the K ee Society seore (KSS - knee and function scores), a specific patellofemoral pain questionnaire (Kujala score) range (motion) (ROM) and a visual analogue scale (VAS) to assess anterior knee pain.

Results: The data obtained were ofran wesing SPSS version 17.0. Continuous variables were expressed as mean \pm SD. Of the 108 patients, 9 prients Were rost to follow-up. Among the remaining 99 patients, 50 were included in denervation group and 9 in on-de Kervation group. In our study, there was no statistically significant difference in Mean KUJALA score preo, atru. $(p>0.05)$. Postoperatively, the mean KUJALA score was significantly higher in denervation group a $6,9,2,24$ months of follow-up when compared to TKR with no denervation $(p<0.05)$. There was no st. tic 4u-cignificant difference in Mean VAS score preoperatively $(p>0.05)$. However, 6, 12 and 24 months afte the o, ration, the mean VAS score was significantly lower in denervation group. There was no statistically nificant, affference in Mean KSS score preoperatively and postoperatively $(p>0.05)$. The mean ROM was sianfican, higher in denervation group than in the group of TKR with no denervation $(p<0.05)$. (cc tinured on next page)

rrespondence: srkdikshith@gmail.com

Deppartment of Orthopedics, SVS Medical College and Hospital,

Mahabubnagar, Telangana State 500062, India

(c) The Author(s). 2020 Open Access This article is licensed under a Creative Commons Attribution 4.0 International License, which permits use, sharing, adaptation, distribution and reproduction in any medium or format, as long as you give appropriate credit to the original author(s) and the source, provide a link to the Creative Commons licence, and indicate if changes were made. The images or other third party material in this article are included in the article's Creative Commons licence, unless indicated otherwise in a credit line to the material. If material is not included in the article's Creative Commons licence and your intended use is not permitted by statutory regulation or exceeds the permitted use, you will need to obtain permission directly from the copyright holder. To view a copy of this licence, visit http://creativecommons.org/licenses/by/4.0/. 
(Continued from previous page)

Conclusion: In our study, less postoperative anterior knee pain, increased range of motion, significantly lower VAS scores were seen in the denervation group compared with non-denervation group. Circumferential denervation of patella during primary TKA along with patellar resurfacing is a safe procedure that improves patient satisfaction, decreases anterior knee pain and improves range of flexion in the postoperative period and at postoperative follow-ups.

Keywords: Total knee arthroplasty, Anterior knee pain, Patelloplasty, Denervation

\section{Introduction}

Anterior knee pain is still a major problem in total knee arthroplasty (TKA) reported in $4-49 \%$ of patients. Often due to patellofemoral etiology, there is no clear consensus as to etiology or treatment [1] of anterior knee pain. This anterior patellofemoral knee pain is one of the major cause of dissatisfaction and morbidity in postTKR patients.

Unfortunately, many aspects of anterior knee pain after TKA have yet to be fully understood. Patellar resurfacing for anterior knee pain reduction in TKA remains controversial, because it has been associated with fracture, subluxation and dislocation of the patella, aseptic loosening, and patella necrosis [2].

In general, patelloplasty with removal of osteophytes along with denervation of the patella by electrocaute v was used for treatment of anterior knee pain [1] $T_{h}$ purpose of our study was to compare the anter $r$ knee pain and clinical outcomes of patelloplasty in $\Gamma K$ vith patellar denervation by electrocautery and without pa lar denervation for a follow-up period of 2 years.

\section{Materials and methods}

This study was conducted among a tal of 108 patients, who underwent TKA at our nstitu tion between June 2015 and December 201 surgeries were performed by a single eon. tients between age 55 to 80 years, who ore cuffering from osteoarthritis, rheumatoid aycritis fonee were included in this study. Patients wio vrevious, $p$ atella surgery/fracture, previous high tibianosta my, revision TKA were excluded from the stady. Of the -08 patients, 55 were included in patellopt. ith electrocautery group and other 53 in nonoctro te $y$ group. The allocation was done by using si iple randomization method. Inside the operation thetre, ratients were allocated to denervation or non- ervation group based on a chit. Neither the operating surgeons nor the assistants knew to which group the patient was allocated prior to the procedure.

All the patients who are planned admitted for Total knee arthroplasty underwent routine blood investigations for surgical profile. Physician fitness \& consent are taken prior to surgery.
$\mathrm{X}$-rays of involved knees in AP and lateral vic were taken. Patellofemoral and tibiofen ral art/ritis was graded. Radiological and clinical ses as done in terms of deformities, crepitus and terior knee pain.

\section{Surgical technique}

Standard surgical ech que involving anterior midline incision (Fig. 1) parapatellar approach (Fig. 2) with retropat 1 fat pad excision (Fig. 3) was used for all natients. Cruciate sacrificing PFC SIGMA implits were used in all cases. Patellar trackino was th en checked with 'no thumb test' after $s$ ating both trial and definitive implants.

ter it plantation of femoral and tibial components, the $\mathrm{P}$ har surface was resurfaced using an electric saw. Both lacets of the patella were reshaped to anatomically mimic the normal shape of the patella. All the marginal osteophytes were removed. Peripheral denervation around patella was performed with electrocautery for a

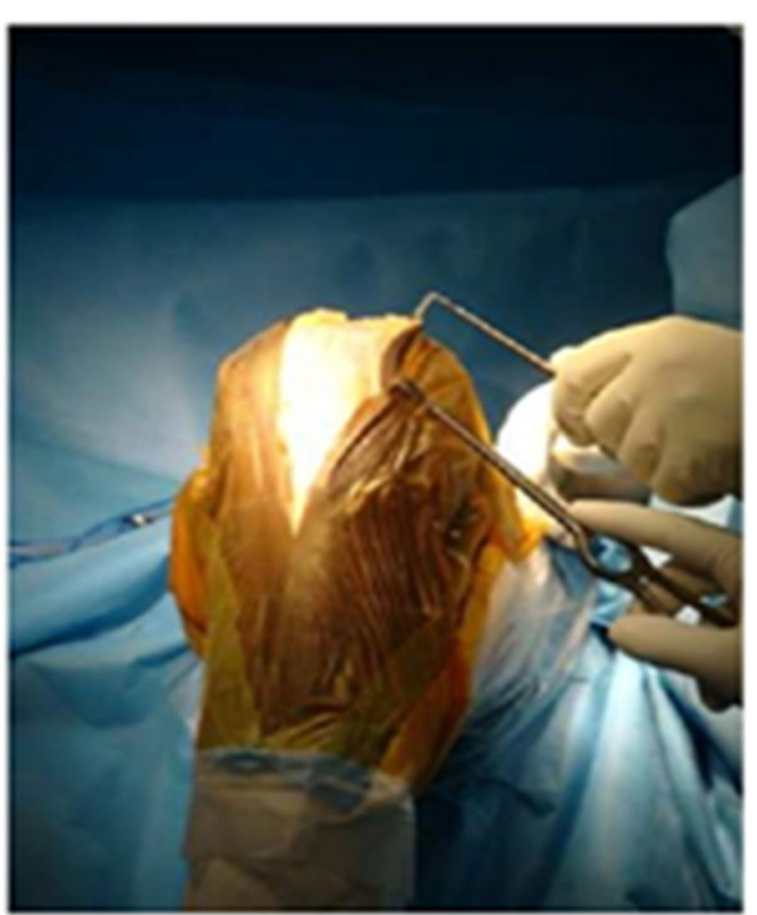

Fig. 1 Standard midline incision over knee 


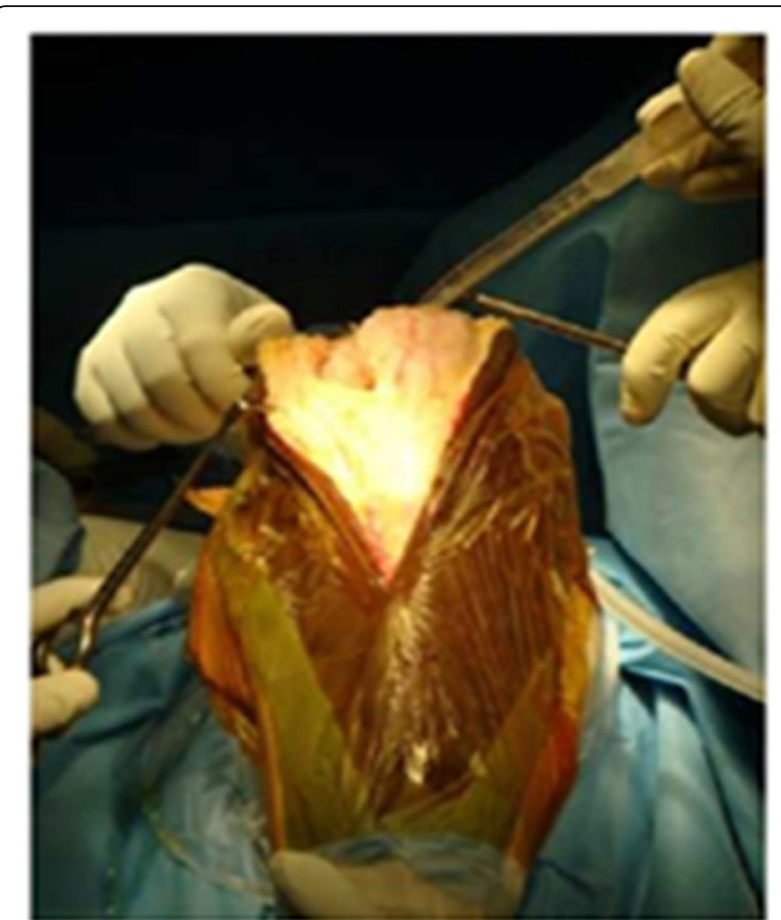

Fig. 2 Medial parapatellar approach depth of 2 to $3 \mathrm{~mm}$ in electrocautery group (Fig. 4). The denervation of the patella was done using a monopolar coagulation diathermy set to $50 \mathrm{~W}$. (Valleylab Inc., Boulder, $\mathrm{CO})$. In non-electrocautery group only patelloplasty was performed. Later, wound was closed in layers $g$ Nor suction drain.

\section{Patient evaluation}

Postoperative X-rays were taken in AP ard la views. Patients were assessed at regular inte vals of 3, , 9, 12 and 24 months.

To assess patient outcomes, sea so determine the Knee Society core $\mathrm{S}$ - knee and function scores), a specific pat femoral ain questionnaire (Kujala score), range on mo (ROM) and a visual analogue scale (VAO) assess nterior knee pain. The total KSS consisto ty momponents, with first one being the Knee Society nction Score and the second the Knee Society in Scory.

Written inform a consent was obtained from all patients, and app oval to use their medical records and to re to te each patient was taken from the Local Rerch t ics Committee.

\section{Rac'ological assessment}

St mdard weight-bearing anteroposterior, lateral and skyline views were taken preoperatively, immediately postoperatively and at the follow-up visits. Pre operatively,

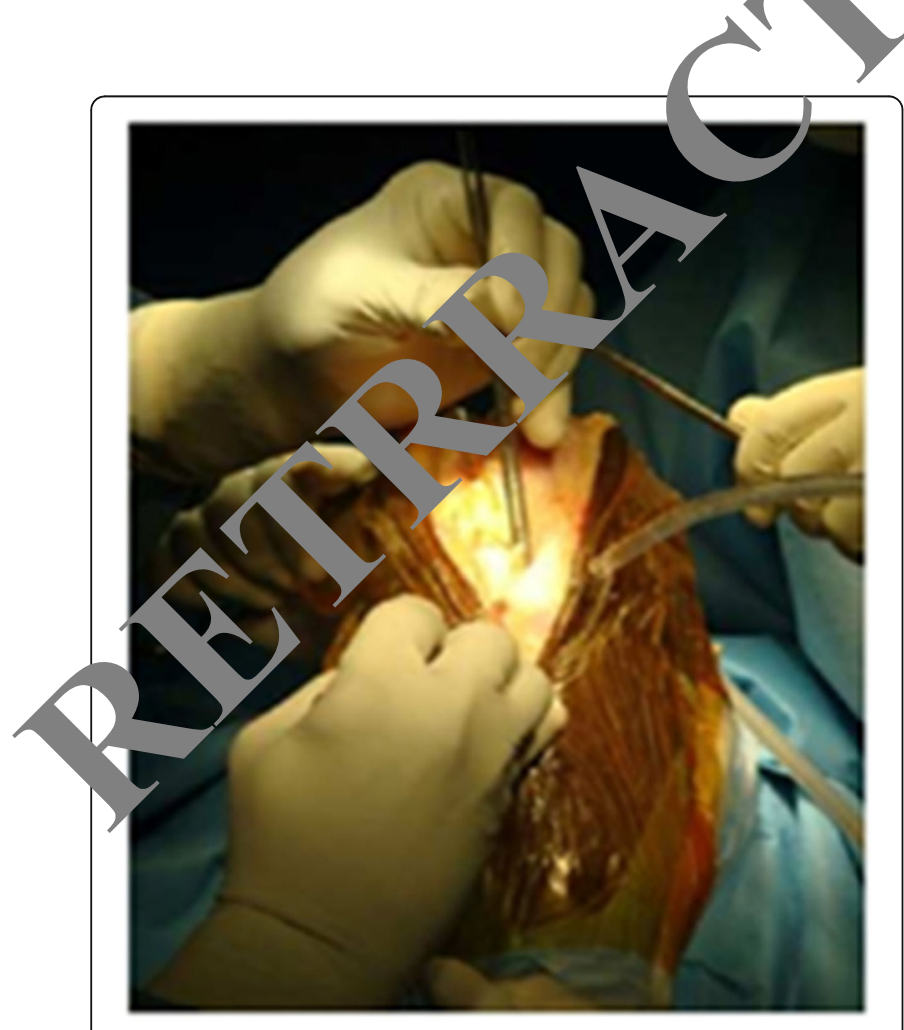

Fig. 3 Retropatellar fat pad excision

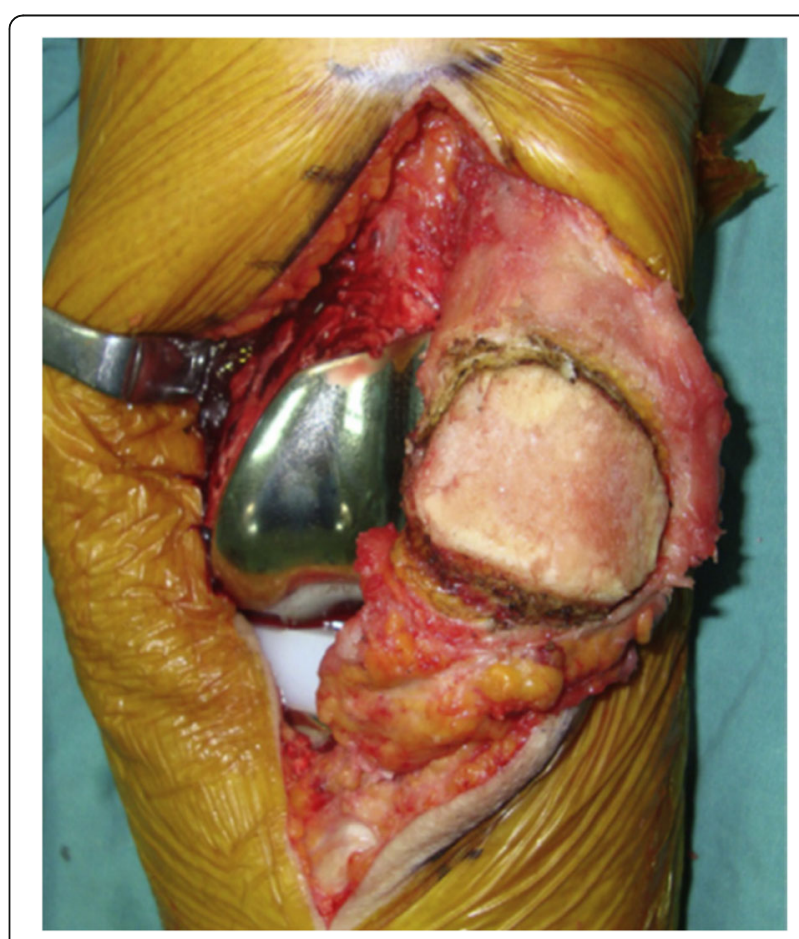

Fig. 4 Circumpatellar coagulation diathermy 
Insall - salvati ratio was assessed. Those with patella alta/baja are excluded from study based on insall ratio.

\section{Method of statistical analysis}

SPSS statistical software version 17.0 (SPSS Inc., Chicago, IL, USA) was used to process the data. We used the following parametric tests: (1) paired $t$ test for intragroup comparison of two variables i.e. Pre- and postoperative values and (2) non-paired $t$ test for intergroup comparison of two variables. Pearson correlation coefficient was used to measure correlation. Continuous variables were be expressed as mean $\pm \mathrm{SD}$. A $P$ value < 0.05 was considered significant.

\section{Results}

Of the 108 patients who underwent TKA, 9 were lost to follow-up. Among the 99 who were studied, 50 were in electrocautery group and 49 in non-electrocautery group. Patients were followed up 3, 6, 12 and 24 months after operation. At all preoperative and postoperative visits, all clinical scores were determined with respect to function, the range of motion VAS etc.

The data obtained were analyzed using SPSS version 17.0. Continuous variables were expressed as mean \pm SD. Appropriate statistical tests were used to determine ou comes of patelloplasty in TKA, with and without coas lation diathermy.

Patients in both study groups were com ar in terms of age, gender, mean age being 63.6 ears. ' was no significant difference in the dis cibution of patients in terms of age $(p>0.05)$. Mean ge in platients with denervation was $62.7 \pm 7.5$ and the n tients without denervation was +8.11 (Table 1). There was no statistically significant ainy, ence in mean age distribution between gry ps $(p>0.05)$ (Table 2). The gender distribution $\mathrm{w}$ groups is also not significant statisticall $-(p>75)$. Male to female ratio was $0.26: 1$.

In our study tho was ${ }^{\circ}$ statistically significant difference in $n$ an KU) $k$ score preoperatively $(p>0.05)$ (Table 3, Fig -). Postoperatively, the mean KUJALA

\begin{tabular}{|c|c|c|c|c|}
\hline & \multicolumn{2}{|c|}{ Denervation } & \multicolumn{2}{|c|}{ Non denervation } \\
\hline & Number & $\%$ & Number & $\%$ \\
\hline & 1 & 2 & 1 & 2 \\
\hline 4) 50 & 3 & 6 & 2 & 4 \\
\hline $51-60$ & 11 & 22 & 13 & 26 \\
\hline 61-70 & 28 & 56 & 23 & 48 \\
\hline$\geq 71$ yrs & 7 & 14 & 10 & 20 \\
\hline Total & 50 & 100 & 49 & 100 \\
\hline Chi square & & 1.20 & $p$ value & 0.877 \\
\hline
\end{tabular}

Table 2 Comparison in terms of mean Age

\begin{tabular}{|c|c|c|c|c|c|c|}
\hline \multirow[t]{2}{*}{ Age } & \multicolumn{2}{|c|}{ Denervation } & \multicolumn{2}{|c|}{ Non denervation } & \multirow{2}{*}{$\begin{array}{l}t \\
\text { value }\end{array}$} & \multirow{2}{*}{$\begin{array}{l}\boldsymbol{p} \\
\text { valu }\end{array}$} \\
\hline & Mean & SD & Mean & $\mathrm{SD}$ & & \\
\hline Age & 62.7 & 7.5 & 63.6 & 8.1 & 0.57 & \\
\hline
\end{tabular}

score was significantly higher in denervation group 6,9,12 months follow-up when compared to TKR wit. no denervation $(p<0.05)$. There was no tistic ly significant difference in mean VAS score $P$ eratively $(p>0.05)$. However, postop ratively at 6,12 and 24 months, the mean VAS fcor was significantly lower in denervation group (1. 4, rg. 6). There was no statistically signifi nt diffe ge in mean KSS score preoperatively and os oratively $(p>0.05)$ (Fig. 7). The mean ROM was signific tly higher in denervation group than no -denervation $(p<0.05)$ (Fig. 8). The patient satista on we was also higher in denervation group (Tà $/ 5$ ) compared with non-denervation gro

\section{Discu. on}

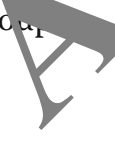

A rior nee pain is reported to postoperatively occur in $u_{1}$ to one-half of all patients receiving TKR. The ultimate goal of TKR is to relieve pain and to improve the knee function. The presence of AKP after TKR is iegatively correlated with patient satisfaction and quality of life.

The pathophysiology of anterior knee pain in osteoarthritis is often uncertain and is frequently multifactorial. Surface incongruities in patella and cartilage is one of the main reason for AKP $[3,4]$.

The major source of this pain is both peri-patellar soft tissue and retropatellar fat pad [5]. Substance-p nociceptive fibres in the peripatellar soft tissue were found to be one of the major cause of this pain $[6,7]$. Electrocautery disables these pain receptors and achieve desensitization or denervation of the anterior knee region.

Disagreement exists in regard of circumpatellar denervation, with some studies finding it beneficial and some studies not [8-11]. We hypothesized that patellar denervation with electrocautery along with patellar

Table 3 Mean Kujala score pre- and postoperatively between groups

\begin{tabular}{|c|c|c|c|c|c|c|}
\hline \multirow[t]{2}{*}{ KUJALA } & \multicolumn{2}{|c|}{ Denervation } & \multicolumn{2}{|c|}{ Non-denervation } & \multirow{2}{*}{$\begin{array}{l}t \\
\text { value }\end{array}$} & \multirow{2}{*}{$\begin{array}{l}\boldsymbol{p} \\
\text { value }\end{array}$} \\
\hline & Mean & SD & Mean & SD & & \\
\hline Preoperatively & 19.2 & 4.03 & 17.7 & 5.94 & 1.45 & 0.148 \\
\hline 3 months & 50.34 & 6.23 & 37.8 & 5.6 & 10.53 & $<0.001$ \\
\hline 6 months & 66.4 & 6.15 & 52.18 & 6.95 & 10.86 & $<0.001$ \\
\hline 12 months & 71.68 & 6.20 & 60.64 & 5.65 & 9.29 & $<0.001$ \\
\hline 24 months & 78.64 & 6.75 & 66.68 & 6.33 & 9.13 & $<0.001$ \\
\hline
\end{tabular}




\section{Mean Kujala between groups}

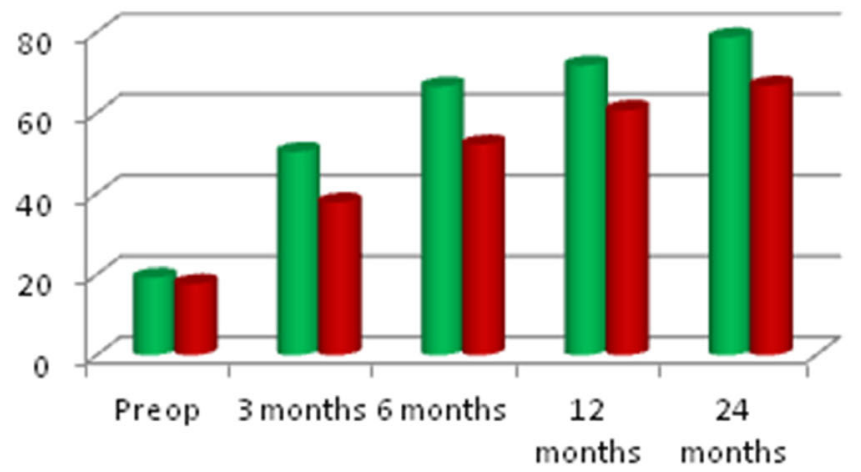

Fig. 5 Mean Kujala score between two groups. The mean Kujala score was higher in denervation groun-at 3(50.34), 60.4$)$, 12 (71.6) and 24 months (78.64) than in non-denervation group. And the difference was significant

resurfacing would have some advantages in terms of reducing the anterior knee pain and improving clinical outcomes after TKA.

In a study, van Jonbergen et al. $[9,10]$ found that $56 \%$ of Dutch orthopedic surgeons performing TKA used circumpatellar electrocautery to prevent anterior knee pain whereas $32 \%$ did not.

We designed a randomized control study with a 1 hypothesis that there is no difference in the outco me between the two groups.

Our results showed that postoperative in nee So ty score, ROM, Kujala score and VAS w re significantly better in the denervation group. These fi lings in licated that patellar denervation by electrocau wuld decrease anterior knee pain and achi clinical outcomes after TKA.

Rand and Gaffey [1] descri d tha electrocautery has potentially harmful effect on ticular cartilage and must be performed ith ca intraoperatively to avoid cartilage trauma.

We have ap liea ccroudutery only to the peripheral rim of the tella $\mathrm{w}_{1}$ a depth of $2-3 \mathrm{~mm}$ to prevent surface exposi

le 4 VAS score pre- and postoperatively between

\begin{tabular}{|c|c|c|c|c|c|c|}
\hline & \multicolumn{2}{|c|}{ Denervation } & \multicolumn{2}{|c|}{ Non denervation } & \multirow{2}{*}{$\begin{array}{l}t \\
\text { value }\end{array}$} & \multirow{2}{*}{$\begin{array}{l}\boldsymbol{p} \\
\text { value }\end{array}$} \\
\hline & Mean & SD & Mean & SD & & \\
\hline Preoperatively & 8.1 & 0.58 & 8.22 & 0.67 & 0.95 & 0.344 \\
\hline 3 months & 3.54 & 1.29 & 4.18 & 2.02 & 1.8 & 0.63 \\
\hline 6 months & 2.52 & 0.7 & 3.14 & 0.7 & 4.4 & $<0.001$ \\
\hline 12 months & 1.68 & 0.65 & 2.52 & 0.50 & 7.2 & $<0.001$ \\
\hline 24 months & 1.34 & 0.47 & 1.6 & 0.53 & 2.56 & 0.012 \\
\hline
\end{tabular}

Vega and folano es $Y$ [12] summarised that circumpatellar election would denervate the patellar rim and effectively desensitize the anterior knee area.

Our findings vere consistent with studies conducted b Pula thi RS et al. [13] in 2013 and Gupta et al. [8], in $\mathrm{rms} f$ age, gender distribution.

In study there was no statistically significant diff rence in mean KUJALA score preoperatively $(p>$ $0.55)$. However, posoperatively the patients were rollowed for 3 months $(p<0.001), 6$ months $(p<$ $0.001), 12$ months $(p<0.001)$ and 24 months $(p<0.001)$ and it was observed that the mean KUJALA score was significantly higher in denervation group than in those without denervation $(p<0.05)$. Ramnadh et al. [13] also observed significant improvement in knee pain (in terms of Kujala score) ( $p=$ $0.02)$ at 3 months $(p=0.14)$ in denervation group but at 6 months $(p=0.13), 9$ months $(p=0.17), 12$ months $(p=$ $0.21)$ and 2 years $(p$ value $=0.20)$ the improvement was not significant compared to both groups.

There was no statistically significant difference in mean VAS score preoperatively $(p>0.05)$. No significant difference in mean VAS score was observed at 3 months postoperatively $(p>0.05)$. However, at 6,12 and 24 months, the mean VAS score was significantly lower in denervation group than when compared to TKR with no denervation $(p<0.05)$. These results are in contrast with the findings by Ramnadh Pulavarthi et al., where VAS scores were not significant at 12 months $(p=0.1)$ and 24 months $(p=0.35)$ in denervation group compared to non-denervation group.

Another study by Saoud [5] involving a total 40 patients who underwent TKA showed that denervation group had a significantly more favorable pain scores.

Sun et al. retrospectively studied clinical outcomes of patelloplasty and non-patelloplasty treatment in 


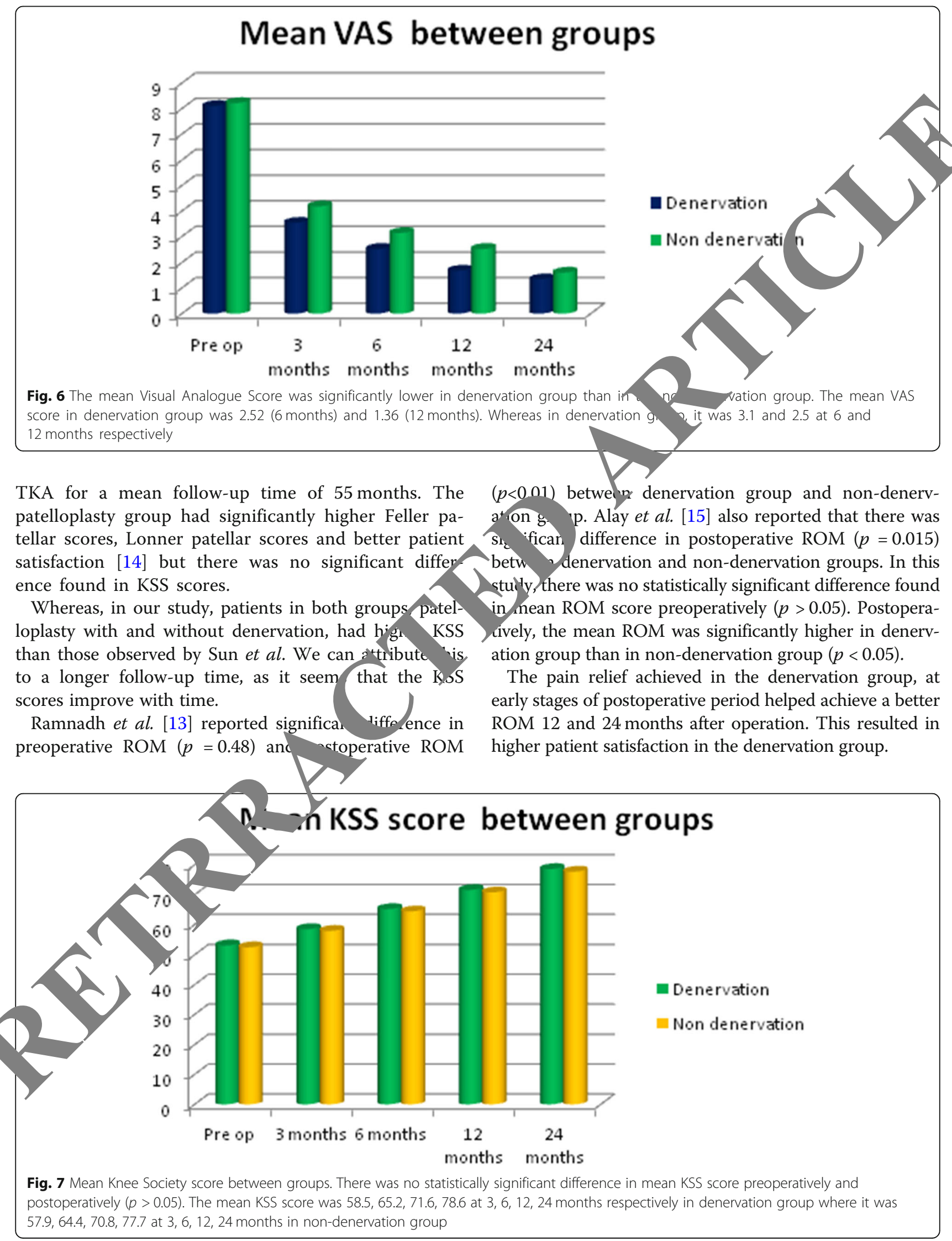




\section{Mean ROM score between groups}

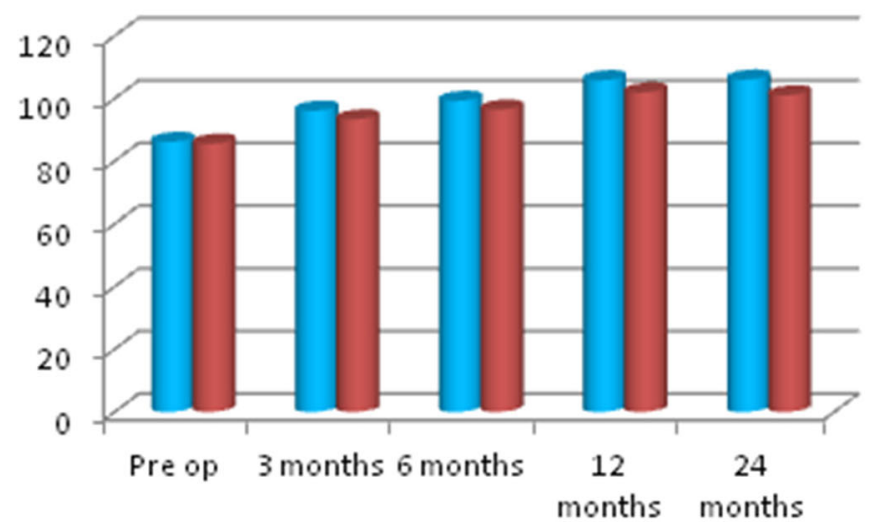

Fig. 8 Mean ROM between two groups. In denervation group the mean ROM was 96, 99, 105, 106 non-denervation group mean ROM was 93, 96, 101, 101 respectively. The difference was statisticall

Single surgeon involvement, using a standardized technique, robust inclusion/exclusion criteria and a minimum 24 months of follow-up time are major strengths of our study. The limitations of the included a small sample size and short-term follow-up. Larger, prospective randomized controlled trials a. longer follow-up studies are needed to better evaluate the effect and long-term results of pa denervation. Also better scoring systems
to developed to evaluate the knee pain after TKA.

\section{Conclusion}

The concept of patellar denervation intriguing, but the which technique is proper remains unclea.

In this study, less postopo tive interior knee pain, increased ROM, signific. ly VAS scores in denervation group yo ob ved as compared with non-denervation rou . However, the study had the limitations of ho. perod of follow-up, small sample size. In onclusio circumferential denervation of patella d,rins rimary TKA with patellar resurfacing is a are proce $\mathrm{e}$ which improves patient satisfactio. te reases anterior knee pain and improves range of fle $n \mathrm{ir}$ the postoperative period and at subseq ent fo, ow-up visits.

ble $\mathbf{5}$ Distribution of patients in terms of patient satisfaction

\begin{tabular}{|c|c|c|c|c|}
\hline \multirow{2}{*}{$\begin{array}{l}\text { Parlent } \\
\text { satisfaction }\end{array}$} & \multicolumn{2}{|c|}{ Denervation } & \multicolumn{2}{|c|}{ Non-denervation } \\
\hline & Number & $\%$ & Number & $\%$ \\
\hline Excellent & 39 & 78 & 27 & 54 \\
\hline Good & 7 & 14 & 12 & 26 \\
\hline Fair & 4 & 8 & 10 & 20 \\
\hline Total & 50 & 100 & 49 & 100 \\
\hline
\end{tabular}

Abbreviations

TKA: Total knee arthrd blasty; AKP: Anterior knee pain; VAS: Visual analogue scale, Qxford knee score; KSS: Knee society score; PD: Patellar

2 ervatio IPD: Non Patellar Denervation; RCT: Randomised Control Trail; Ak Imeri $n$ Knee Society Score; PS: Patellar score; ROM: Range Of Motio WOAAC: Western Ontario and McMaster Universities Arthritis Index; PFA; Pat no Femoral Arthroplasty; AKPS: Anterior Knee Pain Scale (Kujala

\section{Acknowledgements}

Not applicable.

\section{Authors' contributions}

The author(s) read and approved the final manuscript.

Funding

Nil

Availability of data and materials

Not applicable.

\section{Competing interests}

We declare we have no competing interests both financial and non financial.

Received: 29 August 2019 Accepted: 3 August 2020

Published online: 11 September 2020

\section{References}

1. Rand JA, Gaffey TA. Effect of electrocautery on fresh human articular cartilage. Arthroscopy. 1985;1(4):242-6.

2. Baker P, van der Meulen J, Lewsey J, Gregg P. The role of pain and function in determining patient satisfaction following total knee arthroplasty: data from the national joint registry for England and wales. Orthopaedic Proc. 2012;94(SUPP IV):110 Orthopaedic Proceedings.

3. Hirasawa Y, Okajima S, Ohta M, Tokioka T. Nerve distribution to the human knee joint: anatomical and immunohistochemical study. Int Orthop. 2000; 24(1):1-4.

4. Stein DT, Ricciardi CA, Viehe T. The effectiveness of the use of electrocautery with chondroplasty in treating chondromalacic lesions: a randomized prospective study. Arthroscopy. 2002;18:190-3.

5. Saoud AMF. Patellar denervation in non-patellar resurfacing total knee arthroplasty. Pan Arab J Orth Trauma. 2004;8:25-30.

6. Bohnsack M, Meier F, Walter GF, Hurschler C, Schmolke S, Wirth CJ, et al. Distribution of substance-P nerves inside the infrapatellar fat pad and the 
adjacent synovial tissue: a neurohistological approach to anterior knee pain syndrome. Arch Orthop Trauma Surg. 2005;125(9):592-7.

7. Lehner B, Koeck FX, Capellino S, Schubert TE, Hofbauer R, Straub RH. Preponderance of sensory versus sympathetic nerve fibers and increased cellularity in the infrapatellar fat pad in anterior knee pain patients after primary arthroplasty. J Orthop Res. 2008;26(3):342-50.

8. Gupta S, Augustine A, Horey L, Meek RM, Hullin MG, Mohammed A. Electrocautery of patellar rim in primary total knee replacement: beneficial or unnecessary? Bone Joint J. 2010;92(9):1259-61.

9. Van Jonbergen HP, Barnaart AF, Verheyen CC. A Dutch survey on circumpatellar electrocautery in total knee arthroplasty. Open Orthop J. 2010;4:201-3.

10. Van Jonbergen HP, Scholtes VA, van Kampen A, Poolman RW. A randomised, controlled trial of circumpatellar electrocautery in total knee replacement without patellar resurfacing. J Bone Joint Surg Br. 2011;93(8): 1054-9.

11. Fan L, Ge Z, Zhang C, Li J, Yu Z, Dang X, et al. Circumferential electrocautery of the patella in primary total knee replacement without patellar replacement: a meta-analysis and systematic review. Sci Rep. 2015;24:5.

12. Vega J, Golanó P, Pérez-Carro L. Electrosurgical arthroscopic patellar denervation. Arthroscopy. 2006;22(9):1028-e1.

13. Pulavarti RS, Raut W, GJ ML. Patella denervation in primary total knee arthroplasty - a randomized controlled trial with 2 years of follow-up. J Arthroplasty. 2014;29(5):977-81.

14. Sun Y-Q, Yang B, Tong S-L, Sun J, Zhu Y-C. Patelloplasty Versus Traditional Total Knee Arthroplasty for Osteoarthritis. Orthopedics. 2012;35:e343-8. https://doi.org/10.3928/01477447-20120222-14.

15. Altay MA, Ertürk C, Altay N, Akmeșe R, Işıkan UE. Patellar denervation in total knee arthroplasty without patellar resurfacing: a prospective, randomized controlled study. Orthop Traumatol Surg Res. 2012.

\section{Publisher's Note}

Springer Nature remains neutral with regard to jurisdictional claims in published maps and institutional affiliations.

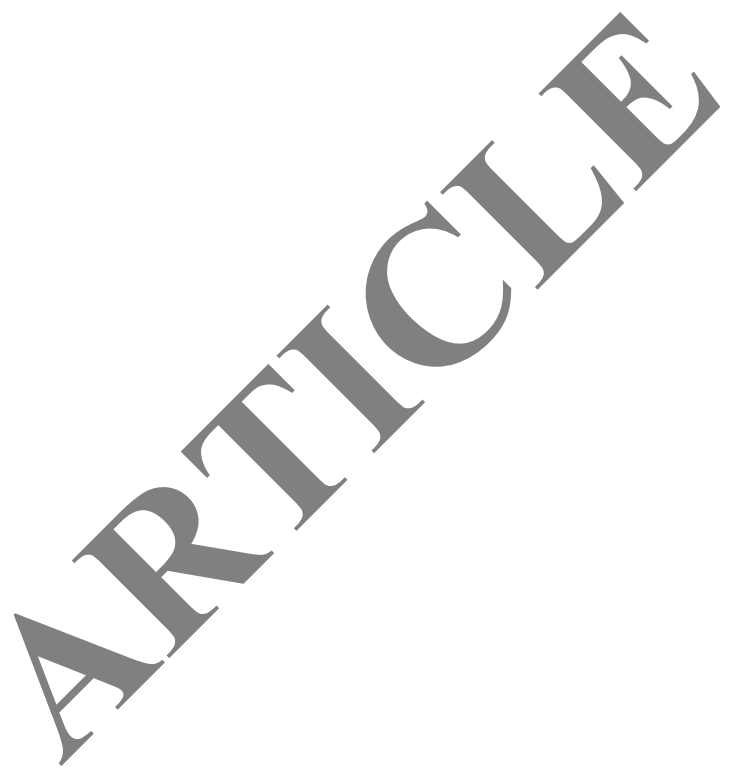

\section{Ready to submit your research? Choose BMC and benefit from:}

- fast, convenient online submission

- thorough peer review by experienced researchers in your field

- rapid publication on acceptance

- support for research data, including large and complex data types

- gold Open Access which fosters wider collaboration and increased citations

- maximum visibility for your research: over $100 \mathrm{M}$ website views per year

At $\mathrm{BMC}$, research is always in progress.

Learn more biomedcentral.com/submissions 